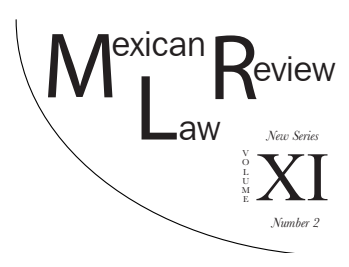

\title{
FREEZING FINANGIAL ASSETS IN THE UNITED STATES AND IN MEXICO: CONTRASTS IN CONSTITUTIONALITY AND LEGAL PARALLELS
}

\author{
Delia Sánchez Castillo*
}

ABSTRACT: The purpose of this article is to understand how asset freezing works in the United States of America and in Mexico, as well as the contrasts and similarities in both systems. The threats posed to civil rights that can arise from asset freezing led us to compare the judicial criteria held by the US Courts and the corresponding reasoning in the Mexican legal system. Alternative rulings from European courts are also considered. Finally, some recommendations are made to improve due process in the Mexican legal system after preventing money laundering and funding terrorism when freezing financial assets.

Keywords: Asset freezing, seizure, Anti-Money Laundering, Combating the Financing of Terrorism.

RESUMEN: El propósito de este artículo es entender cómo funciona la congelación de activos en los Estados Unidos de América y México, sus contrastes y similitudes en ambos sistemas. Las amenazas a los derechos civiles que pueden surgir de la congelación de activos nos llevaron a comparar criterios judiciales sostenidos por los Tribunales de los Estados Unidos y el correspondiente razonamiento en el sistema legal mexicano. También se consideran las decisiones alternativas de los tribunales europeos. Finalmente, se hacen algunas recomendaciones para mejorar el debido proceso en los casos de prevención del lavado de dinero y financiamiento al terrorismo en el sistema legal mexicano al congelar activos financieros.

Palabras Clave: Congelación de activos, embargo incautación, prevención de Lavado de Dinero y Financiamiento al Terrorismo.

* Degree in Law and Specialist in Financial Law by the National Autonomous University of Mexico. She has worked in regulatory and consulting areas at the Institute for the Protection of Banking Savings, the Ministry of Finance and Public Credit and the National Banking and Securities Commission. Email: delosvraz@hotmail.com. 
Esta revista forma parte del acervo de la Biblioteca Jurídica Virtual del Instituto de Investigaciones Jurídicas de la UNAM http://www.juridicas.unam.mx/ https://biblio.juridicas.unam.mx/bjv https://revistas.juridicas.unam.mx/ http://dx.doi.org/10.22201/iij.24485306e.2019.1.13130

\section{TABLE OF CONTENTS}

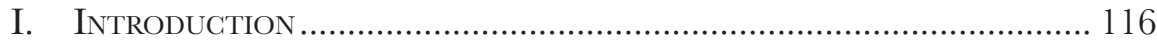

II. The Goncept of Asset Freezing ..................................................... 118

III. International Asset Freezing in Context ………........................ 120

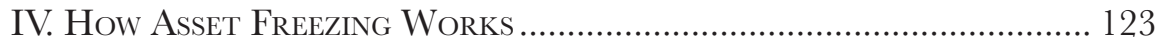

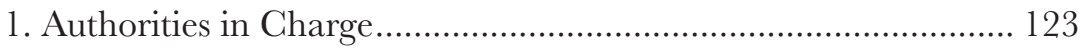

2. The Listing Process .................................................................... 124

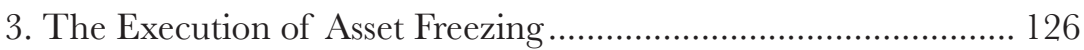

4. The Delisting Process.................................................................... 128

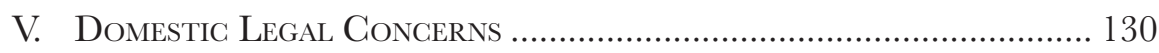

1. Due Process Concerns: Lack of Notification.............................. 130

2. Due Process Concerns: Secret Evidence....................................... 134

3. Infringement of Property Rights ................................................ 135

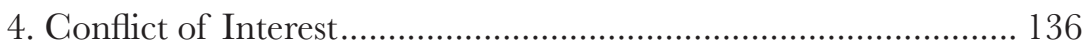

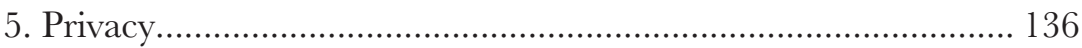

6. The Right to Free Exercise of Religion ………………….......... 137

7. The Right to Free Association .................................................. 138

8. The Right to Free Speech .......................................................... 139

9. Burden of Proof ...................................................................... 140

VI. Beyond the US and Mexican Scope: The European Approach .... 142

1. The Use of Classified Information ............................................ 142

2. The Right to Be Heard .............................................................. 142

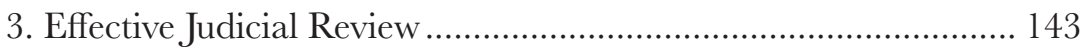

4. Infringement of Property Rights ................................................ 144

5. The Right to Freedom of Movement ........................................... 144

ViI. Final Remarks. Preventing Money Laundering and Financing Terrorism in Mexico: Lessons From US and European DOMESTIC FramewORKS .................................................................... 145

\section{INTRODUCTION}

The Mexican legal system has experienced recent legal modifications to introduce financial asset freezing in order to prevent money laundering and to combat the financing of terrorism. ${ }^{1}$ The US government has been freezing

1 Decreto por el que se reforman, adicionan y derogan diversas disposiciones en materia financiera y se expide la Ley para Regular las Agrupaciones Financieras [Decree through which certain provisions on financial matters are amended, supplemented or repealed and the Law 
assets since the $18^{\text {th }}$ century. ${ }^{2}$ While responding to very different reasons, such measures have always aimed at protecting national security, the economy and international policy. ${ }^{3}$ Consequently, the asset-freezing measure has a rich background in US judicial review, and has extended its influence among UN Member States.

Even though the US legal system does not belong to the same legal tradition as the Mexican one, it has been used as a benchmark because the US government has applied this measure for a long time and has strongly endorsed this measure before the United Nations ${ }^{4}$ as one of the key mechanisms to counter terrorism financing.

Before 9/11, un Member States had been working on international instruments to globally coordinate efforts to fight terrorism. The New York terrorist attacks simply accelerated the adoption of such measures. ${ }^{5}$

Other international organizations, such as Financial Action Task Force (FATF), have urged their members to adopt financial and non-financial asset freezing as a key measure to combat money laundering and suppress terrorism financing. Asset freezing is still enforced despite international human rights concerns, mostly related to due process protection. ${ }^{6}$

Several members of the European Union have also experienced terrorist attacks, as well as the legal consequences of restricting civil liberties. Furthermore, European courts have conducted a thorough analysis to balance the need for measures coherent with current international efforts to combat terrorism that deprive terrorists of financial resources while still adopting a protective approach concerning civil liberties.

However, it might be suitable for the Mexican legal system to follow some of the latest judicial criteria given by US courts, or rather follow the European trend regarding the balance between national security and the protection of civil liberties. In this context, we will analyze whether Mexican legal reforms could be improved by taking into consideration the international experiences of both the United States and Europe.

for the Regulation of Financial Groups is enacted], Diario Oficial de la Federación [D.O.], 10 de Enero de 2014 (Mex.).

2 Bethany Kohl Hipp, Comment, Defending expanded presidential authority to regulate foreign assets and transactions, 17 EMORY INT'L L. REv. 1311, 1311 (2013).

3 Id. at 1365.

4 Lutz Oette, A Decade of Sanctions against Iraq: Never Again! The End of Unlimited Sanctions in the Recent Practice of the uN Security Council, 13 Eur. J.INT'L L., 93, 96 (2002) (discussing the legitimacy of Security Council sanctions).

5 Laura K. Donohue, Article, Anti-terrorist finance in the United Kingdom and United States, 27 Mich. J. INT'L L. 303, 306 (2006).

6 Adele J. Kirschner, Security Council Resolution 1904 (2009): A Significant Step in the Evolution of the Al-Qaida and Taliban Sanctions Regime?, 70 Zeitschrift Für Ausländisches Öffentliches Recht Und Völkerrecht [ZaöRV] 585, 591 (2010) (Ger.). 
Esta revista forma parte del acervo de la Biblioteca Jurídica Virtual del Instituto de Investigaciones Jurídicas de la UNAM http://www.juridicas.unam.mx/ https://biblio.juridicas.unam.mx/bjv https://revistas.juridicas.unam.mx/ http://dx.doi.org/10.22201/iij.24485306e.2019.1.13130

\section{The Concept of Asset Freezing}

According to the financial statutory laws, freezing financial assets is a preventative administrative procedure ${ }^{7}$ ordered by the Secretariat of Finance and Public Credit, on behalf of the Mexican federal government, and executed by Mexican financial institutions, which are obligated to cease all dealings involving the accounts or are banned from celebrating operations with blocked persons. This precautionary measure is only applicable to counter two federal crimes, namely financing terrorism and money laundering. Additionally, reconsiderations or administrative reviews are carried out by the same authority that ordered the financial asset freezing. ${ }^{8}$

Even though the term "freezing of assets" is broadly understood, statutory rules refer instead to the "list of blocked persons" [Lista de personas bloqueadas]. ${ }^{9}$ The inclusion of a natural or legal person's data on the list has the effect of a general order to freeze assets in the possession of financial institutions and whose owner's data match those on the list.

There are other preliminary measures such as the temporary seizure or freezing of interest-bearing accounts held by financial institutions as a result of a breach of contract or failure to fulfill tax obligations; but these shall not be considered in this article. These actions are commonly known in the Mexi-

7 COMPETENCIA PARA CONOCER DEL JUICIO DE AMPARO INDIRECTO PROMOVIDO CONTRA LA ORDEN DE ASEGURAMIENTO Y BLOQUEO DE UNA CUENTA banCARIA DICTADA POR EL TITULAR DE LA unidad de inteligencia financiera de la Secretaría de Hacienda y Crédito Público, sin QUE PREVIAMENTE EXISTA UNA INVESTIGACión DEL MinisTerio PÚBlico. CorResponde a un JUEZ DE Distrito en materia administrativa, Tribunales Colegiados de Circuito [T.C.C.] [Supreme Court], Semanario Judicial de la Federación y su Gaceta, Décima Época, tomo IV, Octubre de 2016, Tesis I.10o.P.2 P (10a.), Página 2847 (Mex.).

8 Ley de Instituciones de Crédito [L.I.C.] [Credit Institutions Law], as amended, Art. 115, paras. nine to eleven, Diario Oficial de la Federación [D.O.], 18 de Julio de 1990 (Mex.); Ley del Mercado de Valores [L.M.V.] [Stock Market Law], as amended, Art. 212, paras. four to six, Diario Oficial de la Federación [D.O.], 30 de diciembre de 2005 (Mex.); Ley de Fondos de Inversión [L.S.I.] [Investment Corporations Law], as amended, Art. 91, paras. seven to nine, Diario Oficial de la Federación [D.O.], 4 de junio de 2001 (Mex.); Ley General de Organizaciones y Actividades Auxiliares del Crédito [L.G.O.C.] [General Law of Organizations and Activities Related to Credit], as amended, Arts. 95, paras. nine to eleven, 95 Bis, paras. six to eight, Diario Oficial de la Federación [D.O.], 14 de enero de 1985 (Mex.); Ley de Uniones de Crédito [L.U.C.] [Credit Unions Law], as amended, Art. 129, paras. eight to ten, Diario Oficial de la Federación [D.O.], 20 de agosto de 2008 (Mex.); Ley de Ahorro y Crédito Popular [L.A.C.P.] [Popular Saving and Credit Law], as amended, Art.124, paras. six to eight, Diario Oficial de la Federación [D.O.], 4 de junio de 2001 (Mex.); Ley para Regular las Actividades de las Sociedades Cooperativas de Ahorro y Préstamo [L.R.A.S.C.A.P.] [Law to Regulate the Activities of Saving and Loan Cooperative Companies], as amended, Art. 72 paras. four to six, Diario Oficial de la Federación [D.O.], 13 de agosto de 2009 (Mex.).

9 Id. 
can legal system as a seizure ["embargo"] ${ }^{10}$ and can be brought before a court or an administrative judge.

Similarly, this article does not focus on "civil forfeiture." On Mexican legal grounds, the forfeiture of property is a civil action concerning a permanent deprivation of goods if so ruled by a court. Pursuant to Article 22 of the Mexican Constitution, such a measure is only applicable in cases related to six federal crimes, namely organized crime, drug trafficking, kidnapping, car theft, human trafficking and illicit enrichment. ${ }^{11}$ This civil action runs parallel to, but does not depend on criminal procedure. ${ }^{12}$

However, it is worth mentioning that the Federal Law for Civil Forfeiture also set forth precautionary measures similar to asset freezing. ${ }^{13}$ It is described as a provisional immediate order prohibiting any transaction of funds or assets, whether financial or non-financial.

From the perspective of the US legal system, "seizure," "blocking of assets," or "asset freezing" in general, refer to a temporary deprivation of property that does not vest the assets in the government. ${ }^{14}$ Consequently, an eventual settlement or return of assets can take place. On the other hand, confiscation or forfeiture refers to a permanent deprivation of property. ${ }^{15}$

In the United States, economic sanctions are governed by the 1977 International Emergency Economic Powers Act (IEEPA), which grants the President far-reaching authority to "deal with any unusual and extraordinary threat, which has its source in whole or substantial part outside the United States, to the national security, foreign policy, or economy of the United States." ${ }^{\prime 6}$ This grants the President the power to nullify, transfer, prohibit or otherwise

10 Procedimiento de INMOVILIZACión DERIVAdo DE CRÉditos FISCALES FIRMES. SE RIGE EXCLUSIVAMENTE POR LAS REGLAS PREVISTAS EN LOS ARTÍCUlOS 156-BIS Y 156-TER DEL CóDigo FisCal de la Federación (Legislación vigente en 2010), Segunda Sala de la Suprema Corte de Justicia [S.C.J.N.] [Supreme Court], Semanario Judicial de la Federación y su Gaceta, Décima Época, tomo IV, Diciembre de 2011, Tesis 2a./J. 20/2011, Página 3064 (Mex.).

11 Constitución Política de los Estados Unidos Mexicanos [Const.], as amended, Art. 22, Diario Oficial de la Federación [D.O.], 5 de febrero de 1917 (Mex.).

12 Extinción de DOMinio. La AUTONOMía A QUE SE REFIERE EL ARTículo 22 DE LA CONSTITUCIÓN POLÍTICA DE LOS ESTADOS UNIDOS MEXICANOS, ENTRE EL PROCEDIMIENTO RELATIVO Y EL Penal no es absoluta, sino Relativa, Primera Sala, [S.C.J.N] [Supreme Court], Gaceta del Semanario Judicial de la Federación, Décima Época, Libro 17, tomo I, Abril de 2015, Tesis 1a./J. 21/2015 (10a.), 340 (Mex.).

13 Ley Federal de Extinción de Dominio, Reglamentaria del Artículo 22 de la Constitución Política de los Estados Unidos Mexicanos [L.F.E.D.] [Federal Law for Civil Forfeiture, Regulatory of the Article 22 of the Political Constitution of the United Mexican States] as amended, Art. 12 Bis, D.O., 29 de Mayo de 2009 (Mex.). (The confiscation measure is governed by the LFED).

14 Montgomery E. Engel, Note, Donating "Blood Money": fundraising for international terrorism by United States charities and the government's efforts to constrict the flow, 12 Cardozo J. Int'l \& Comp. L. 251, 260 (2004).

15 Hipp, supra note 2, at 1365-66.

1650 U.S. Code $\S 1701$. 
regulate any acquisition, holding or use by any person of any property that is subject to the jurisdiction of the United States and in which any foreign country has any interest. However, this power is limited to national emergencies declared by executive order. ${ }^{17}$

Historically, the IEEPA had been used almost exclusively against foreign nations or in nation-to-nation diplomacy. This changed in 1995 when President Clinton declared a national emergency in response to terrorist threats to disrupt the Middle East peace process by issuing Executive Order 12947. Then such power was applied to individuals, such as terrorist, narcotics traffickers in Colombia and those contributing to the proliferation of chemical or biological weapons. ${ }^{18}$

Afterward, President George W. Bush expanded the application of the IEEPA by issuing several orders targeting the terrorist financial livelihood of States, non-State groups, and individuals. ${ }^{19}$

After 9/11, President Bush exercised IEEPA authority to declare a national emergency by Executive Order 13244, on September 24, 2001. This executive order addressed the issue of persons who commit, threaten to commit or support terrorism. It authorizes the freezing of assets belonging to designated persons and banning transactions involving any assets of interest to these persons, organizations or whoever assists in, sponsors, or provides financial, material or technological support to terrorism. ${ }^{20}$ This order created the "Specially Designated Global Terrorist" (SDGT) list. ${ }^{21}$

Currently, the Office of Foreign Assets Control (OFAC) - the agency in charge of executing asset freezing orders - has about twenty-eight sanctions programs. ${ }^{22}$

The next section gives a description of the international context of freezing assets as a measure to prevent money laundering and counter financing terrorism.

\section{International Asset Freezing in Context}

In the international arena, the following circumstances drove the Mexican government to modify its legal framework in order to fulfill its international commitments.

17 J. David Pollock, Note, Administrative Fustice: Using Agency Declaratory Orders in the Fight to Staunch the Financing of Terrorism, 33 Cardozo L. Rev. 2171, 2174 (2012).

18 Id. at 2175.

19 Id. at 2175.

20 Hipp, supra note 2, at 1367.

21 Nicole Nice-Petersen, Note, Fustice for the "Designated": The process that is due to alleged U.S. financiers of terrorism, 93 GEO. L.J. 1387, 1406 (2005).

22 See Department of the Treasury-Office of Foreign Assets Control, Sanctions Programs and Country Information, available at https://werre.treasury.gov/resource-center/sanctions/Programs/ Pages/Programs.aspx (last visited on Jan. 11, 2018). 
1. The un Convention against Illicit Traffic in Narcotic Drugs and Psychotropic Substances, subscribed in the capital of Austria on December 20, 1988 (hereafter the Vienna Convention) ${ }^{23}$ required Member States to criminalize money laundering and to establish asset freezing as a provisional measure for the eventual confiscation of proceeds, property or any other things referring to the offences specified in the convention.

2. Regarding the terrorist activities in Afghanistan, Resolution 1267 (1999), issued by the un Security Council on October 15, 1999, ${ }^{24}$ under Chapter VII of the Charter of the United Nations, ${ }^{25}$ required Member States to freeze funds and other financial resources, owned or controlled directly or indirectly by the Taliban. Under this resolution, no resources should be made available to or for the benefit of the Taliban or any undertaking owned or controlled, directly or indirectly, by the Taliban. However, the Committee may authorize some exceptions on a case-bycase basis on the grounds of humanitarian need. ${ }^{26}$

3. Article 8 of the International Convention for the Suppression of the Financing of Terrorism, adopted by the UN General Assembly in $1999^{27}$ (hereafter the Terrorism Financing Convention) encourages State Parties to take measures "for the identification, detection and freezing or seizure of any funds used or allocated" for the purpose of financing terrorism, for purposes of possible forfeiture.

4. Article 12 of the UN Convention against Transnational Organized Crime, signed in Palermo, Italy, in December $2000^{28}$ (hereafter the Palermo Convention), requires State Parties to adopt measures to enable the identification, tracing, freezing or seizure and confiscation of proceeds, property, equipment or other instrumentalities of crime derived from offences covered by the Convention.

23 Convention against Illicit Traffic in Narcotic Drugs and Psychotropic Substances U.N. Doc. E/CONF.82/15; 28 ILM 493 (1989).

24 See S.C. Res. 1267, 4, U.N. Doc. S/RES/1267 (Oct. 15 1999), see S.C. Res. 2253, pmbl. 15, U.N. Doc. S/RES/2253 (Dec. 17, 2015), The UN Security Council Resolution 2253 (2015) changed the name of the "Al-Qaida Sanctions List" to "ISIL (Da'esh) \& Al-Qaida Sanctions List".

25 Oette, supra note 4, at 96. Under Chapter VII of the Charter of the United Nations, the Security Council has broad powers. Once it has determined a threat to the peace, a breach of the peace, or an act of aggression-pursuant to Article 39 of the Charter of the United Nations, the Council can impose sanctions in accordance with Article 41 of the Charter of the United Nations, which contains a non-exhaustive list of non-military measures. The scope of the measures and their duration fall entirely within the powers granted to the Security Council.

26 See S.C. Res. 1452, 1-2, U.N. Doc. S/RES/1452 (Dec. 20, 2002), amended by S.C. Res. 1735, U.N. Doc. S/RES/1735 (Dec. 22, 2006).

27 International Convention for the Suppression of the Financing of Terrorism, U.N. Doc. A/RES/54/109; 39 ILM 270 (2000); TIAS No. 13075.

28 United Nations Convention against Transnational Organized Crime, 40 ILM 335 (2001); UN Doc. A/55/383 at 25 (2000); UN Doc. A/RES/55/25 at 4 (2001). 
Esta revista forma parte del acervo de la Biblioteca Jurídica Virtual del Instituto de Investigaciones Jurídicas de la UNAM http://www.juridicas.unam.mx/ https://biblio.juridicas.unam.mx/bjv https://revistas.juridicas.unam.mx/ http://dx.doi.org/10.22201/iij.24485306e.2019.1.13130

5. As a consequence of the $9 / 11$ attacks, the un Security Council issued Resolution 1373, on September 28, 2001, which demanded that Member States freeze funds and other financial assets or economic resources of persons who commit, or attempt to commit, terrorist acts or participate in or facilitate the commission of terrorist acts; of entities owned or controlled directly or indirectly by such persons; and of persons and entities acting on behalf of, or at the direction of, such persons and entities. ${ }^{29}$

6. The Financial Action Task Force (FATF) ${ }^{30}$ of which the USA and Mexico are members ${ }^{31}$ issued standards of universal application for the suppression of terrorist financing and money laundering.

Recommendation 4 urges country members to adopt measures similar to those set forth in the Vienna Convention, the Palermo Convention, and the Terrorism Financing Convention. ${ }^{32}$ Subsequently, country members are required to enable their competent authorities to freeze or seize and confiscate the following, without prejudicing the rights of bona fide third parties: property laundered, proceeds from, or instrumentalities used in or planned for use in money laundering or predicate offences. ${ }^{33}$

Additionally, FATF Recommendation 6 stresses that country members should comply with UN Security Council resolutions which require countries to freeze the funds or other assets of, and to ensure that no funds or other assets are made available, directly or indirectly, to or for the benefit of, any person or entity either designated by, or under the authority of, the UN Security Council or designated by a country pursuant to resolution 1373 (2001). ${ }^{34}$

29 See S.C. Res. 1373, 1 c), U.N. Doc. S/RES/1373 (Sep. 28, 2001).

30 The fATF is an inter-governmental body established in 1989 by the Ministers of its Member jurisdictions (which currently stand at 36 members and 8 FATF-Style Regional Bodies). The objectives of the FATF are to set standards and promote effective implementation of legal, regulatory and operational measures for combating money laundering, terrorist financing and other related threats to the integrity of the international financial system. See http://wrerr:fatfgafi.org/home/.

31 See http://werere:fatf-gafi.org/about/membersandobservers/.

32 FATF (2012-2017), International Standards on Combating Money Laundering and the Financing of Terrorism \& Proliferation, FATF, Paris, France, p. 10, available at http://werere:fatf-gafi.org/media/fatf/ documents/recommendations/pdfs/FATF\%20Recommendations\%202012.pdf (last visited on Jan. 11, 2018).

33 A "predicate offense" is an earlier offense that can be used to enhance a sentence levied for a later conviction. Predicate offenses are defined by statute and are not uniform from state to state. Black's Law Dictionary, 3429 (8th ed. 2004). See supra note 32. Under the FatF Interpretive Note to Recommendation 3 (criminalization of money laundering), para. 2, Predicate offences may be described by reference to all offences; or to a threshold linked either to a category of serious offences; or to the penalty of imprisonment applicable to the predicate offence (threshold approach); or to a list of predicate offences; or a combination of these approaches.

34 See supra note 32. Recommendation 6. 
It is important to note that the three UN conventions mentioned require Member States to freeze assets as a provisional measure for the purpose of eventual confiscation in cases involving the crimes covered by the conventions. Yet, un resolutions 1267 (1999), 1373 (2001) and FATF Recommendations 4 and 6 urge country members to freeze assets as a provisional measure to counter terrorist financing and money laundering, even when there is no criminal prosecution or regardless of this.

In Mexico, these instruments were the main reason for the introduction of asset freezing as a precautionary administrative measure. Consequently, in seeking to comply with the aforementioned international instruments, the "Decree amending, supplementing or repealing certain provisions in financial matters and issuing the law to Regulate Financial Groups," commonly known as the "Financial Reform," was published in the Federal Official Gazette on January 10, 2014. This reform introduced the "List of Blocked Persons."

\section{How Asset Freezing Works}

\section{Authorities in Charge}

In general, in the United States each sanction program has its own rules. So, President Clinton's Executive Order 12947 delegated authority to the Secretary of State to designate persons or entities that have committed, were likely to commit, or provided support for acts of terrorism in the Middle East. It also empowered the Secretary of the Treasury to determine the persons or entities owned or controlled by said designees. ${ }^{35}$

Similarly, President Bush's Executive Order 13224 (2001) delegated authority to the Secretary of State to ascertain the persons or entities that have committed, or posed a significant risk of committing, acts of terrorism. Additionally, it gave authority to the Secretary of the Treasury to determine persons or entities "owned or controlled by, or act for or on behalf of" the persons or entities that "assist in, sponsor, or provide financial, material, or technological support for ... or other services to or in support of" specified persons or entities; or that were "otherwise associated with" said entities. ${ }^{36}$

In Mexico, financial statutory laws grant the Mexican Secretariat of Finance and Public Credit the authority to issue a List of Blocked Persons and dictate the procedure to introduce, modify or remove the entry of any name on the list. ${ }^{37}$

\footnotetext{
35 Pollock, supra note 17, at 2175.

36 Id. at 2176.

37 See supra note 8.
} 
So, it is clear that in the United States, the power to freeze assets basically lies in two main bodies: the Department of State identifying threats to national security and the Department of the Treasury determining the direct and indirect participation of entities owned or controlled by those named as threats. On the other hand, in Mexico, asset freezing is an exclusive power of the Secretariat of Finance. The national authority in charge of national security is not involved at all.

\section{The Listing Process}

In the United States, the designation process is carried out by the Office of Foreign Assets Control (OFAC), an office in the Department of the Treasury that collaborates with several other federal agencies. This office identifies possible targets to be added to the list of designated terrorists. All classified and nonclassified information is gathered in a record compiled by the OFAC and forms the basis for this list. The record is then analyzed by the legal office of the Department of Justice in order to establish legal designations. The final decision is taken by the National Security Council Policy Coordinating Committee on Terrorist Financing, composed of representatives from the Central Intelligence Agency (CIA), the Federal Bureau of Investigation (FBI), and the Departments of Treasury, State, Defense, Justice, and Homeland Security ${ }^{38}$

After 9/11, the IEEPA was amended by the Act for Uniting and Strengthening America by Providing Appropriate Tools Required to Intercept and Obstruct Terrorism, best known as the Patriot Act. ${ }^{39}$ Consequently, Section 1702 (a) (1) (B) of the IEEPA allows freezing assets during an investigation. ${ }^{40}$ Thus, even though the designation and the record have not been formally completed, an entity can find its assets frozen.

In Mexico, the rules to introduce, modify or remove entries on the List of Blocked Persons ${ }^{41}$ empower the Mexican Secretariat of Finance to introduce

\footnotetext{
38 Pollock, supra note 17, at 2179.

39 Hipp, supra note 2, at 1353.

4050 U.S. Code $\S 1702$. The relevant text points out the following: "Presidential authori-
} ties" "(a) In general" "(1) At the times and to the extent specified in section 1701 of this title, the President may, under such regulations as he may prescribe, by means of instructions, licenses, or otherwise:" [... "B) investigate, block during the pendency of an investigation, regulate, direct and compel, nullify, void, prevent or prohibit, any acquisition, holding, withholding, use, transfer, withdrawal, transportation, importation or exportation of, or dealing in, or exercising any right, power, or privilege with respect to, or transactions involving, any property in which any foreign country or a national thereof has any interest by any person, or with respect to any property, subject to the jurisdiction of the United States; and." [Emphasis added].

41 See Disposiciones de carácter general a que se refiere el artículo 115 de la Ley de Instituciones de Crédito[L.I.C.] [General Provisions Referred to in Article 115 of the Credit Institutions Law] as amended, ch. XV, Diario Oficial de la Federación [D.O.], 20 de abril de 2009; Disposiciones de carácter general a que se refieren los artículos 115 de la Ley de Instituciones 
or modify entries by taking into consideration the lists issued by the un Security Council pursuant to its own Resolutions 1267 (1999) and 1373 (2001), and lists released by international organizations or inter-governmental groups. However, no guidelines or principle has been provided to do so.

As for national sources, the Mexican Secretariat can add people when national authorities have enough proof to prosecute them for performing terrorist activities, financing terrorism and money laundering; as well as those

de Crédito en relación con el 87-D de la Ley General de Organizaciones y Actividades Auxiliares del Crédito y 95-Bis de este último ordenamiento, aplicables a las sociedades financieras de objeto múltiple [General Provisions Referred to in Article 115 of the Credit Institutions Law in relation with Article 87-D and 95 Bis of the General Law of Organizations and Activities Related to Credit, applicable to Non-Bank Banks] as amended, ch. XIII, Diario Oficial de la Federación [D.O.], 17 de marzo de 2011 (Mex.); Disposiciones de carácter general a que se refiere el artículo 95 de la Ley General de Organizaciones y Actividades Auxiliares del Crédito, aplicables a las Casas de Cambio [General Provisions Referred to in Article 95 of the General Law of Organizations and Activities Related to Credit applicable to Money Exchange Firms] as amended, ch. XIV, Diario Oficial de la Federación [D.O.], 25 de septiembre de 2009 (Mex.); Disposiciones de carácter general a que se refiere el artículo 95 Bis de la Ley General de Organizaciones y Actividades Auxiliares del Crédito, aplicables a los transmisores de dinero a que se refiere el artículo 81-A Bis del mismo ordenamiento [General Provisions Referred to in Article 95 Bis of the General Law of Organizations and Activities Related to Credit, applicable to Money Remitters] as amended, ch. XIV, Diario Oficial de la Federación [D.O.], 10 de abril de 2012 (Mex.); Disposiciones de carácter general a que se refiere el artículo 95 Bis de la Ley General de Organizaciones y Actividades Auxiliares del Crédito, aplicables a los centros cambiarios a que se refiere el artículo 81-A del mismo ordenamiento [General Provisions Referred to in Article 95 Bis of the General Law of Organizations and Activities Related to Credit, applicable to Low-Amount Foreign Exchange Entities] as amended, ch. XIV, Diario Oficial de la Federación [D.O.], 10 de abril de 2012 (Mex.); Disposiciones de carácter general a que se refiere el artículo 95 de la Ley General de Organizaciones y Actividades Auxiliares del Crédito aplicables a los Almacenes Generales de Depósito [General Provisions Referred to in Article 95 of the General Law of Organizations and Activities Related to Credit, applicable to Bonded Warehouses] as amended, ch. XIII, Diario Oficial de la Federación [D.O.], 31 de diciembre de 2014 (Mex.); Disposiciones de carácter general a que se refiere el artículo 212 de la Ley del Mercado de Valores [General Provisions Referred to in Article 212 of the Stock Market Law] as amended, ch. XVI, Diario Oficial de la Federación [D.O.], 9 de septiembre de 2010 (Mex.); Disposiciones de carácter general a que se refiere el artículo 91 de la Ley de Fondos de Inversión [General Provisions Referred to in Article 91 of the Investment Corporations Law] as amended, ch. XIII, Diario Oficial de la Federación [D.O.], 31 de diciembre de 2014 (Mex.); Disposiciones de carácter general a que se refiere el artículo 129 de la Ley de Uniones de Crédito [General Provisions Referred to in Article 129 of the Credit Unions Law] as amended, ch. XIV, Diario Oficial de la Federación [D.O.] 26 de octubre de 2012 (Mex.); Disposiciones de carácter general a que se refiere el artículo 124 de la Ley de Ahorro y Crédito Popular [General Provisions Referred to in Article 124 of the Popular Saving and Credit Law] as amended, ch. XVI, Diario Oficial de la Federación [D.O.], 31 de diciembre de 2014 (Mex.); Disposiciones de carácter general a que se refieren los artículos 71 y 72 de la Ley para Regular las Actividades de las Sociedades Cooperativas de Ahorro y Préstamo [General Provisions Referred to in Articles 71 and 72 of the Law to Regulate the Activities of Saving and Loan Cooperative Companies] as amended, ch. XVI, Diario Oficial de la Federación [D.O.], 31 de diciembre de 2014 (Mex.). 
who have been condemned for such crimes, and those who refuse to give information about the mentioned crimes, or conceal the origin, objectives, location or property of funds derived from said crimes.

In short, in the United States, the final decision to blacklist someone is taken by a high level group in which departments involved in national security play an important role while in Mexico, the designation process is carried out solely by the Secretariat of Finance.

In Mexico, the bases for creating the List of Blocked Persons can be classified into two groups: international causes and national ones. As international sources are more active, the determination of blocked persons might be largely deemed as an administrative procedure to assist in the execution of blocking orders issued by countries that have suffered terrorist attacks or have designated certain individuals or entities as terrorist supporters. Nonetheless, other domestic criminal causes are also considered for the List of Blocked Persons.

\section{The Execution of Asset Freezing}

In the United States, once an individual or an entity has been blacklisted, the OFAC orders to block all "property or interests in property" held by the designated entity or individual in the United States or within the control or possession of US nationals. As a result of the blocking order, the rights to exercise any powers and privileges of ownership are transferred indefinitely and exclusively to the OFAC although the legal title of these frozen assets remains with the designated individual or entity. ${ }^{42}$

The OFAC prohibits US persons from dealing in assets that have been blocked or from providing any kind of services for the benefit of designated persons or entities, including legal services, charitable contributions or donations intended to "relieve human suffering." ${ }^{43}$ Nonetheless, under limited circumstances, a license to engage in otherwise prohibited transactions may be granted by OFAC to designees or third parties. ${ }^{44}$

The term "US person" means any US citizen, permanent resident alien, entity organized under the laws of the United States (including foreign branches), or person in the United States. ${ }^{45}$ Consequently, this obligation is applicable not only to financial entities, but also to any kind of natural or legal person in the United States.

\footnotetext{
42 Pollock, supra note 17, at 2177.

4331 C.F.R. $\$ 94.204,595.204 .594 .406(b), 595.406(b)$. Exec. Order No. 12,947, 60 Fed.
} Reg. 5079, 5080 (Jan. 23, 1995); Exec. Order No. 13,224, 66 Fed. Reg. 49,079, 49,080 (Sept. 23, 2011). Pollock, supra note 17, at 2177.

4431 C.F.R. $\$ 594$ Subpart E, § 595 Subpart E (2012). Pollock, supra note 17, at 2179.

4531 C.F.R. $\$ 594.315, \S 595.315$. 
All US persons who have in their possession or control any property or interests in blocked property, including financial institutions that receive and block payments or transfers, are required to report to the OFAC, within 10 business days from the date said property becomes blocked. ${ }^{46}$

In Mexico, the Mexican Secretary of the treasury notifies financial institutions when an entity or an individual has been so designated. The financial institutions that are obliged to freeze accounts or banned from celebrating operations with blocked persons are banks, brokerage firms (casas de bolsa); investment fund operators and distributor companies of investment fund shares (sociedades operadoras y sociedades distribuidoras de acciones de fondos de inversión), money exchange firms (casas de cambio); entities engaged in low-amount foreign exchange known as centros cambiarios; money remitters (transmisores de dinero); multiple purpose financial institutions (sociedades financieras de objeto múltiple); ${ }^{47}$ savings and loan associations (sociedades financieras populares), financial cooperative associations (sociedades cooperativas de ahorro y préstamo); community financial associations (sociedades financieras comunitarias), credit unions and general deposit warehouses (almacenes generales de depósito); according to the provisions of their respective statutory laws. ${ }^{48}$

Once an obliged financial institution has realized that one of their clients' or users' data match the List of Blocked Persons, it must basically do three things. First, it must cease all dealings involving the designee's accounts or the delivery of any kind of services that benefit the designated persons or entities. Secondly, an Unusual Transaction Report (UTR) ${ }^{49}$ must be filed with the Mexican Secretariat of Finance within twenty-four hours after finding a match.

A UTR is a form by which a financial institution informs the Mexican Secretariat of Finance and its Financial Intelligence Unit (FIU) ${ }^{50}$ of its suspicions or reasonable grounds to suspect that the relevant funds might proceed from criminal activity, or be a match on the list. ${ }^{51}$

Thirdly, the financial institution must inform the blocked individual or entity in writing and must include the following information: $\left.{ }^{52} 1\right)$ the accounts and transactions that have been frozen since the identification data match, 2)

\footnotetext{
$46 \quad 31$ C.F.R. $\S 501.603$.

47 Generally known as non-bank Banks.

48 See supra note 8.

49 See supra note 32, Unusual Transaction Report (UTR) under the International Standards
} on Combating Money Laundering and the Financing of Terrorism \& Proliferation; 12 CFR $\S 390.355$, Suspicious Activity Reports (SARs), under the Bank Secrecy Act.

50 See supra note 32, Recommendation 29. See also https://egmontgroup.org/en/content/financial-intelligence-units-fius. Reglamento Interior de la Secretaría de Hacienda y Crédito Público [Internal Regulations of the Secretariat of Finance and Public Credit] as amended, Art. 15, Diario Oficial de la Federación [D.O.], 11 de septiembre de 1996 (Mex.).

51 See supra note 32, Recommendation 20.

52 See supra note 41. 
the applicable law and procedure, and 3) the clarification that any existing claims may be filed before the FIU within the following ten business days.

Additionally, the Mexican legal system allows some humanitarian exceptions in accordance with Resolution 1452 (2002) of the UN Security Council. Consequently, a blocked person might request a license to access blocked funds to pay for basic expenses, including the provision of legal services.

Up to this point, we can say that one big difference in assets freezing is its scope. In the United States, the measure covers financial and non-financial assets, and is mandatory for any person in the United States. However, in Mexico, this measure only applies to financial assets and is mandatory for the above-mentioned financial institutions.

The consequences of being blacklisted appear to be similar in both legal systems. Basically, the obliged subjects must stop dealing in the assets of or providing any service to individuals or entities who have been designated as a blocked person, in addition to filing a report with the competent financial authority.

Both the US and the Mexican regimes permit designees to access certain blocked funds to pay for basic living expenses, including limited legal services, in compliance with UN Security Council resolutions.

\section{The Delisting Process}

In the United States, removal from the list is possible on grounds of mistaken identity or an error if the blocked individual or entity challenges the designation. The interested party must submit a request in writing to OFAC to demonstrate that the State should not have seized their property or that they were innocent owners. However, at no point does the petitioner have the opportunity to review any classified evidence that the various agencies may have compiled against him. ${ }^{53}$

OFAC designations could be subject to judicial review by district courts, pursuant to the Administrative Procedure Act (APA). Consequently, the review is governed by the "arbitrary and capricious" standard, which means that courts will review whether, given the relevant factors, the agency acted reasonably and within the scope of its authority. Over time, a highly deferential standard of review has been given to the President in the exercise of his powers under the IEEPA. ${ }^{54}$

Moreover, as a result of the enhanced power granted to the US President after 9/11, the Patriot Act gave the President the power to submit classified evi-

\footnotetext{
53 Sumeet H. Chugani, Comment, Benevolent blood money: Terrorist exploitation of zakat and its complications in the war on terror, 34 N.C.J. INT'L L. \& Com. REg. 601, 620 (2009).

54 Id. at 635-636.
} 
dence in camera and ex parte. ${ }^{55}$ This means that the Attorney General can present classified evidence against a blocked entity to the court without the presence of the blocked entity's attorney and without ever disclosing this evidence to the party whose assets are frozen, depriving the designated entity of the usual right to confront the evidence against it. ${ }^{56}$ In other words, courts are allowed to consider evidence that would otherwise be inadmissible under the Federal Rules of Evidence. ${ }^{57}$

In Mexico, the relevant rules ${ }^{58}$ establish a procedure before an administrative authority, the Financial Intelligence Unit (FIU), which is a Mexican Secretariat of Finance unit that functions as an administrative judge. ${ }^{59}$

Based on the information provided by the financial institution that has blocked the accounts or denied rendering any service, the blocked person or entity can bring their claims before the FIU in writing and offer evidence. The FIU will then issue its decision explaining whether the removal is granted or not.

The blocked persons can be removed from the list when the abovementioned administrative procedure ends in an acquittal, when international organizations or intergovernmental groups remove the blocked person from their lists, when national authorities deem that the reasons for inclusion are no longer applicable, or when a criminal judge acquits the defendant of carrying out terrorist activities, financing terrorism and money laundering.

The Mexican review process afforded by the rules is focused on correcting false positives instead of challenging the causes of the asset freezing order or the inclusion of a person's data on the List of Blocked Persons. This is especially worrying when the reason for that insertion is due to UN Security Council sanctions because the review process would not help the designee revoke the Security Council designation. So, an affected person would have her assets frozen for as long as she is on the UN list.

In summary, both systems have established an administrative procedure to permit designees to be removed from the corresponding list. Nevertheless,

5550 U.S. Code $\S 1702$. The pertinent text reads as follow: “(c) Classified information. In any judicial review of a determination made under this section, if the determination was based on classified information (as defined in section 1(a) of the Classified Information Procedures Act) such information may be submitted to the reviewing court ex parte and in camera. This subsection does not confer or imply any right to judicial review." [Emphasis added].

56 Nice-Petersen, supra note 21, at 1390.

57 Donohue, supra note 5, at 375.

58 See supra note 41.

59 Alternatively, blocked persons can directly bring a claim before federal courts, through an Amparo. See Constitución Política de los Estados Unidos Mexicanos [Const.], as amended, Art. 107, section IV, Diario Oficial de la Federación [D.O.], 5 de febrero de 1917 (Mex.). Ley de Amparo, reglamentaria de los artículos 103 y 107 de la Constitución Política de los Estados Unidos Mexicanos [Amparo Law that regulates the implementation of Articles 103 and 107 of the Mexican Constitution], as amended, Art. 1, section I, Diario Oficial de la Federación [D.O.], 2 de abril de 2013 (Mex.). 
neither can be considered to provide sufficient due process protection because they are more concerned with correcting false positives than reviewing the causes that motivated the listing.

The following section discusses the main constitutional and legal concerns arising from the deployment of the asset freezing measure in an effort to suppress fundraising of terrorism and money laundering.

\section{Domestic Legal Goncerns}

Despite the widespread understanding and commitment of UN Member States on the compliance and enforcement of un Security Council resolutions and inter-governmental bodies' recommendations to combat terrorist activities and money laundering, the asset freezing measure has raised much criticism and many concerns about its lawfulness in the light of fundamental rights, ${ }^{60}$ mainly due process standards.

Although the constitutionality of blocking assets has been questioned several times, US courts have seldom held up those claims. This has been understood as a preference to not interfere with the Executive's foreign policy and national security functions. ${ }^{61}$

On the other hand, the Mexican judiciary has not yet ruled on the legal and constitutional concerns involving the freezing of assets, considering the relatively new ${ }^{62}$ introduction of the asset freezing measure.

Similarly, regional courts in Latin America have not reviewed the issue. ${ }^{63}$ This lack of legal criteria leads one to understand how US constitutional provisions have extended their influence into international arena.

The main concerns in the legal order involving the freezing of assets are described below.

\section{Due Process Concerns: Lack of Notification}

In the United States, any citizen or person within the United States deprived of his or her property must be given timely, adequate notice of the

\footnotetext{
60 Michael Bothe, Security Council's Targeted Sanctions against Presumed Terrorists, 6J. INT’L CRIM. Just. 541, 544-545 (2008) (Discussing the remedies against Security Council decisions).

61 Hipp, supra note 2, at 1365.

62 Recently the Mexican Supreme Court has discussed and adopted different criterion. However, the legal reasoning was not publicly available when this work was finished. See http:// werce.internet2.scjn.gob. $m x /$ red2/comunicados/noticia.asp?id=4603.

63 There is no evidence of any relevant decision from the Latin-American national or regional courts before September 1, 2017.
} 
charges against him or her and a meaningful opportunity to be heard, pursuant to the Fifth Amendment Due Process Clause. ${ }^{64}$

Nevertheless, after 9/11, noting terrorists' ability to "transfer funds or assets instantaneously," Executive Order 13244 explicitly withheld prior notice to the affected entities of the measures taken under its authority on the grounds that notice would render such measures "ineffectual." 65

The courts have found that despite the failure of notice and hearing, these do not amount to due process violations. ${ }^{66}$ The courts have deemed that a presidential declaration of a national emergency under the IEEPA constitutes an extraordinary situation whereby notice and hearing after seizure did not amount to a denial of due process. The courts have also found that the US government satisfied the requirements for a postponement of notice and hearing until after seizure, since: ${ }^{67}$ (1) the deprivation served an important government interest, in this case, combating terrorism; (2) prompt action was necessary to prevent the transfer of assets prior to the blocking order; and (3) government officials blocked the assets in accordance with the IEEPA. ${ }^{68}$

Likewise, the courts have determined that due process rights were not violated because notification would have had an impact on security or other US foreign policy goals, and that an SDGT obtained a written opportunity to be heard post-deprivation when it submitted materials to the OFAC for consideration. ${ }^{69}$

In Mexico, every government action interfering with any person's exercise of property rights must be made by means of a warrant submitted by an authorized official. ${ }^{70}$

The requirement of a warrant ensures the existence of a government action, its content and scope. It also allows the affected person access to adequate defense. ${ }^{71}$ The warrant must give sufficient information of the facts that

64 Mullane v. Cent. Hanover Bank \& Trust Co., 339 U.S. 306, 313 (1950), cited on NicePetersen, supra note 21, at 1404.

65 Exec. Order No. 13,224 \& 10, 66 Fed. Reg. at 49,081. Pollock, supra note 17, at 2176.

66 Kathryn A. Ruff, Note, Scared to donate: An examination of the effects of designating Muslim charities as terrorist organizations on the First Amendment Rights of Muslim donors, 9 N.Y.U. J. LEGIS. \& Pub. Pol'y 447, 460 (2005/2006).

67 Calero-Toledo v. Pearson Yacht Leasing Co., 416 U.S. 663, 679-80, 94 S.Ct. 2080, 40 L.Ed.2d 452 (1974) (the Supreme Court defined the circumstances that "present an 'extraordinary' situation in which postponement of notice and hearing until after seizure d[oes] not deny due process").

68 Holy Land Found. 219 F. Supp. 2d at 57. Chugani, supra note 53, at 625.

69 Id. Chugani, supra note 53, at 626.

70 Constitución Política de los Estados Unidos Mexicanos [Const.] as amended, art. 16 pfo. 1, Diario Oficial de la Federación [D.O.], 5 de febrero de 1917 (Mex.). "No one shall be molested in his person, family, domicile, papers, or possessions, except by virtue of a written order of the competent authority stating the legal grounds and justification for the action taken."

71 Competencia de las aUtoridades administrativas. El mandamiento escrito QUe CONTIENE EL ACTO DE MOLESTIA A PARTICULARES DEBE FUNDARSE EN EL PRECEPTO LEGAL QUE LES OTORGUE LA ATRIBUCIÓN EJERCIDA, CITANDO EL APARTADO, FRACGIÓN, INCISO O SUBINCISO, Y EN 
Esta revista forma parte del acervo de la Biblioteca Jurídica Virtual del Instituto de Investigaciones Jurídicas de la UNAM http://www.juridicas.unam.mx/ https://biblio.juridicas.unam.mx/bjv https://revistas.juridicas.unam.mx/ http://dx.doi.org/10.22201/iij.24485306e.2019.1.13130

led the corresponding authorities to issue a given government action or the legal grounds that motivated the interference ${ }^{72}$ and show that the adopted measure is proportional in the light of the goals of the law. ${ }^{73}$ Consequently, this lack or error leads to the assumption that a violation of constitutional protection has been committed. ${ }^{74}$

In view of the above arguments, the Political Constitution of the United Mexican States does not provide any exception to or restriction on this protection. Under these circumstances, the asset freezing order or the inclusion of any person's name on the List of Blocked Persons could be understood as an interfering government act, according to the first paragraph of Article 16 of the Mexican Constitution. Asset freezing obstructs the exercise of property rights when the owner cannot use or dispose of his or her own resources. ${ }^{75}$

Following the given procedure, the legal grounds on which the designation was based, and the facts that led to this designation are only provided when the FIU rules on the claims brought before it by the designee, but not before. Subsequently, when the relevant rules order financial institutions to cease dealings with accounts held by designees or prohibit the rendering of any service, and these rules do not instruct the Mexican Secretariat of Finance to serve a warrant or notice, even after the assets have been frozen, there is a clear violation of Article 14 of the Mexican Political Constitution. Thus, the rules are highly questionable regarding their compliance with this guarantee

CASO DE QUE NO LOS CONTENGA, SI SE TRATA DE UNA NORMA COMPLEJA, HABRÁ DE TRANSGRIBIRSE LA parte correspondiente, Segunda Sala de la Suprema Corte de Justicia de la Nación [S.C.J.N.] [Supreme Court], Semanario Judicial de la Federación y su Gaceta, Novena Época, tomo XXII, Septiembre de 2005, Tesis 2a./J. 115/2005, Página 310 (Mex.).

72 Fundamentacion y motivacion, Segunda Sala de la Suprema Corte de Justicia de la Nación [S.C.J.N.] [Supreme Court], Semanario Judicial de la Federación y su Gaceta, Séptima Época, tomo VI, Tesis 260, Apéndice de 1995, Página 175 (Mex.).

73 Principio de proporcionalidad. Se vulnera Cuando SE PERmita la ReVisión de documentos de una Persona, COn vocablos genéricos, Cuarto Tribunal Colegiado en Materia Civil del Primer Circuito [T.C.C.], Semanario Judicial de la Federación y su Gaceta, Novena Época, tomo XXVIII, Septiembre de 2008, Tesis I.4o.C.157 C, Pag. 1390 (Mex.). ReanuDACIÓN DEL PROCEDIMIENTO TRAS LARGA INACTIVIDAD, DEBE NOTIFICARSE PERSONALMENTE, Cuarto Tribunal Colegiado en Materia Civil del Primer Circuito [T.C.C.], Semanario Judicial de la Federación y su Gaceta, Novena Época, tomo XXVI, Septiembre de 2007, Tesis I.4o.C.124, Página 2625 (Mex.).

74 FUNDAMENTACiÓN Y MOTIVACIÓN. LA DIFERENCIA ENTRE LA FALTA Y LA INDEBIDA SATISFACCIÓN DE AMBOS REQUISITOS CONSTITUCIONALES TRASCIENDE AL ORDEN EN QUE DEBEN ESTUDIARSE LOS CONCEPTOS DE VIOLACión y A LOS EFECTOS DEL FA LLO PROTECTOR, Tribunales Colegiados de Circuito [T.C.G.] [Supreme Court], Semanario Judicial de la Federación y su Gaceta, Novena Época, tomo XXVII, Febrero de 2008, Tesis I.3o.C.J/47, Página 1964 (Mex.).

75 INMOVILIZACIÓN DE CUENTAS BANCARIAS. LA ORDEN RELATIVA EMITIDA POR LA AUTORIDAD FISCAL DEBE ESTAR FUNDADA Y MOTIVADA, AUNQUE SE DIRIJA A UNA INSTITUCIÓN FINANCIERA Y NO al contribuyente, Segunda Sala de la Suprema Corte de Justicia de la Nación [S.G.J.N.] [Supreme Court], Semanario Judicial de la Federación y su Gaceta, Décima Época, tomo 2, Libro XXIII, Agosto de 2013, Tesis 2a./J. 79/2013 (10a.), Página 901 (Mex.). 
since the Mexican Constitution does not establish any exception to serve warrants or notices in cases of interfering government actions.

Moreover, UN Security Council Resolution 2253 (2015) has recently required Member States ${ }^{76}$ to take all possible measures to notify or inform the listed individual or entity of the listing in a timely manner and to include in the notification a narrative summary of the reasons being listed for, a description of the effects of the listing, the committee's procedures for considering delisting requests including the possibility of submitting such a request to the Ombudsperson, ${ }^{77}$ and available exemptions, ${ }^{78}$ as well as the possibility of submitting such requests through the Focal Point mechanism. ${ }^{79}$

Regarding the above, the Mexican mechanism is far from complying with the UN standard as the relevant rules do not require any notification from the Mexican government. Surprisingly, a federal court ruled that even when the blocked person does not know of the government actions or its motives to freeze assets, such action is not deemed unconstitutional or arbitrary as its legality is presumed.$^{80}$ Consequently, the power to freeze assets must be weighed against the protection of the financial system and the national economy.

So far, it is clear that in the United States, the courts have shown a strong deferential approach to the actions taken by the President under IEEPA authority. The courts have developed an objective standard to justify the postponement of notification. There is overwhelming pressure to protect national security at the expense of the human rights of a few.

In the Mexican scenario, the civil liberties have been put aside despite the international recommendation to serve notice to designees even when no emergency has been declared or experienced, and even when financial asset freezing is only applicable to two conducts: money laundering and financing terrorism.

76 S.C. Res. 1735, 11, U.N. Doc. S/RES/1735 (Dec. 22, 2006). Initially, Resolution 1735 (2006), paragraph 11, had required serving notice or informing the listed individual or entity of the designation, in the country or countries where the individual or entity was believed to be located and, in the case of individuals, the country of which the person is a national (to the extent this information be known).

77 S.C. Res. 1735, annex II, U.N. Doc. S/RES/1735 (Dec. 23, 2006). S.C. Res. 2083, 43, U.N. Doc. S/RES/2083 (Dec. 17, 2012).

78 S.C. Res. 1452, U.N. Doc. S/RES/1452 (Dec. 20, 2002). S.C. Res. 1735, 15, 17 and 18, U.N. Doc. S/RES/1735 (Dec. 23, 2006).

79 S.C. Res. 2253, 53, U.N. Doc. S/RES/2253 (Dec. 17, 2015).

80 Congelamiento de CUENTAS bancarias atribuido a La UNIDAD DE INTELIGENCia FinanCIERA DE LA SECRETARÍA DE HACIENDA Y CRÉDito PÚBliCo. AUn CUANDO EL QUEJOSO DESCONOZCA ESE ACTO O SUS MOTIVOS, ES IMPROCEDENTE CONCEDER LA SUSPENSIÓN CON EFECTOS RESTITUTORios en su contra. Tribunales Colegiados de Circuito [T.C.C.] [Supreme Court], Gaceta del Semanario Judicial de la Federación, Décima Época, tomo IV, Junio de 2016, Tesis IV.2o.A.123 A (10a.), Página 2879 (Mex). See also supra note 8. 


\section{Due Process Concerns: Secret Evidence}

According to the Fifth Amendment of the US Constitution, the Due Process Clause prohibits the government from depriving any person of life, liberty, or property without due process of law. As a general rule, the due process system requires that each party have the same opportunity to refute the adversary's evidence by providing evidence to the contrary. Surprisingly, under the new anti-terrorism regulation, defendants are not given any opportunity to confront the classified evidence used against them. Besides, the Patriot Act permits assets to be blocked pending investigation and to submit classified evidence in camera and ex parte, which could lead to freezing assets based on scarce or irrelevant evidence ${ }^{81}$ and without any time limit.

US courts have generally upheld the ability to confront witnesses and respond to evidence as a central part of due process. Nevertheless, where national security is concerned, the courts have historically been reluctant to interfere in due process claims. In this regard, the courts have upheld the use of in camera, ex parte evidence against an entity pending investigation when Congress and the President have determined the need to keep government information secret. The courts have also denied due process challenges, asserting that (1) the notification received at the time of the blocking assets was appropriate in view of pressing circumstances related to national security; and (2) the OFAC written review process provides an adequate opportunity to be heard. ${ }^{82}$

On the other hand, in Mexico and following the arguments presented in the previous section, every single governmental act must be warranted in writing, pointing out the applicable law and the circumstances that made that law applicable. Consequently, it would not be legally possible to freeze financial assets based on classified information.

Once a financial institution finds a match on the list, it would only inform the designee that her data matches the List of Blocked Persons. However, the financial institution lacks sufficient information to explain the facts and reasons why the person or entity has been included on the List of Blocked Persons.

Being included on the List of Blocked Persons might involve a grievance against an individual, as far as he had not received a written warrant from the authority explaining the causes of the inclusion on the List. In such a case, the individual would be deprived of appropriate information to mount a fair defense. Precisely, these are the kinds of situations Article 16 of the Mexican Constitution aims to prevent.

In sum, even though freezing financial assets based on secret evidence would not be possible under Mexican law, the lack of serving notice to designees amounts to a similar situation, as designees are unaware of specific

\footnotetext{
81 Chugani, supra note 53, at 634-635.

82 Global Relief Found. 207 F. Supp. 2d 779, 808. Nice-Petersen, supra note 21, at 1401.
} 
facts and reasons for being blacklisted and are thus incapable of preparing an adequate defense. In this respect, both the US and the Mexican systems have a considerable area of opportunity to grant better protection of basic human rights.

\section{Infringement of Property Rights}

In the United States, it has also been argued that blocking assets constitutes an uncompensated taking, ${ }^{83}$ in terms of property rights and in violation of the Taking Clause contained in the Fifth Amendment. Thereupon, the US government has stated that a blocking order does not constitute a taking since freezing does not entail a title transfer.

Over the years, courts have consistently rejected claims based on similar considerations. In the context of the IEEPA, courts have ruled that blocking under executive orders is a temporary deprivation and does not vest the assets with the government. ${ }^{84}$ Nevertheless, some courts have cautiously suggested at the possibility that a long-term blocking order may have evolved into vesting property in the United States ${ }^{85}$ or, at least at the lower tier, some courts have found it an infringement of property rights. ${ }^{86}$

On the other hand, in Mexico, while the Supreme Court of Justice has not ruled on the infringement of property rights in cases of financial institutions' freezing assets within the context of preventing money laundering and terrorist financing, its recent intervention has been limited to stating that similar preventive measures in forfeiture proceedings entail an interference action but do not entail the deprivation of property rights. During the imposition of this precautionary measure, the affected person or entity still holds property right, but an encumbrance is placed on it so as to temporarily prevent this right from being fully exercised. ${ }^{87}$

As the Mexican Supreme Court has recognized that these kinds of preventative measures involve acts of government interference on an individual's

83 "There is a taking of property when government action directly interferes with or substantially disturbs the owner's use and enjoyment of the property. - Also termed constitutional taking." Black's Law Dictionary, 4553 (8th ed. 2004).

84 Holy Land Found. 219 F. Supp. 2d 57, 77.

85 Hipp, supra note 2, at 1364.

86 Kindhearts for Charitable Humanitarian Dev. v. Geithner, 647 F. Supp 2d at 871. Pollock, supra note 17, at 2185.

87 Extinción de DOMinio. Los ARTículos 11 A 14 y 16 a 18 DE LA LEY RELATIVA PARA EL DISTRITO FEDERAL, SOBRE LA IMPOSICIÓN DE MEDIDAS CAUTELARES, NO VIOLAN EL ARTÍCULO 22 DE la Constitución Política de los Estados Unidos Mexicanos, Primera Sala de la Suprema Corte de Justicia de la Nación [S.C.J.N.] [Supreme Court], Semanario Judicial de la Federación y su Gaceta, Décima Época, tomo 1, Abril de 2015, Tesis 1a. CXXXVII/2015 (10a.), Página 514 (Mex.). 
property right, serving a warrant would undoubtedly be needed to carry out the freezing of assets, pursuant to Article 16 of the Political Constitution of the United Mexican States. However, the opinion of the Mexican Supreme Court does not consider that this temporary measure could be extended indefinitely. In these circumstances, a long-term asset freezing would be equated to an infringement of property rights.

In short, despite the historically reluctant position of US courts to sustain the deprivation of property rights, they now seem to be more aware of the possible infringement of this right. In Mexico, this debate has not yet begun, as an indefinite extension of asset freezing has not been brought before Mexican Courts. However, in analogue cases, without considering PML/FT objectives, the Mexican Supreme Court has ruled that freezing assets is a preventative restriction on property rights.

\section{Conflict of Interest}

In the United States, conflicts of interest might arise when a designee, who has had his or her assets frozen, applies to the OFAC for a license to release certain funds to pay legal expenses, among other reasons. Basically, Executive branch officials are in control of who can sue and how actively the lawsuit can be pursued if they allow the release of the funds. ${ }^{88}$

In the Mexican legal system, the situation is similar. According to UN resolutions, a blocked person or entity can request a license to access blocked funds in order to cover basic life expenses, the fulfillment of contract obligations previously incurred with a financial institution or legal services. However, this request may entail a conflict of interest since the officials authorized to give this license - the FIU- are the same ones who carry out the corresponding administrative proceedings, and against whom judicial proceedings could be potentially brought.

The applicable rules in both systems do not establish any provision to prevent conflicts of interest nor do they provide any principle or guideline for granting this request. Consequently, blocked persons are subjected to the discretion of the relevant authority. In short, both systems struggle with the same problem. One possible solution would be for an independent judge to rule on the petition for a license and thus avoid a conflict of interest.

\section{Privacy}

In the United States, any federal agency can now obtain sensitive and private data without a subpoena or judicial intervention when investigating one

\footnotetext{
88 Donohue, supra note 5, at 416.
} 
of the approximately two hundred possible offenses under the Patriot Act. ${ }^{89}$ In January 2002, Assistant Attorney General Michael Chertoff notified the Senate Banking Committee that with the new information-gathering powers, "the principal provisions of the Right to Financial Privacy Act no longer apply to letter requests by a government authority authorized to conduct investigations or intelligence analysis for purposes related to international terrorism". 90

In Mexico, financial service user's private data is protected against unlawful transmission by the statutory law that governs financial institution transactions. For example, in the banking sector, Article 142 of the Credit Institutions Law (LIC) prohibits credit institutions from providing information about accounts or services to any person other than the one with the legal right to receive such information. However, the exceptions and conditions under which financial institutions are allowed to transmit or share information with some authorities are specified in the same provision. ${ }^{91}$

The Mexican Secretariat of Finance and Public Credit is among those allowed to request personal data in order to prevent money laundering and terrorist fundraising. ${ }^{92}$ Therefore, the Mexican legal system has no major concern in this field.

\section{The Right to Free Exercise of Religion}

In the United States, it has been widely believed that terrorists are funding their objectives through charitable organizations, particularly those focused on fulfilling Muslim obligations, like the zakat - the obligation to pay two and a half percent of their wealth when it exceeds a minimum level. ${ }^{93}$ It is commonly believed that charity organizations are attractive targets for terrorist entities due to the reluctance to scrutinize the use of money collected in countries where the zakat and Sadaqah (supporting charitable works through voluntary contributions) are religious obligations. Moreover, the US Government does not easily discern whether the charity that collects funds for humanitarian causes is actually being utilized for that purpose or used as a monetary source to support terrorism. ${ }^{94}$

\footnotetext{
89 Id. at 407.

90 Id. at 408.

91 Secreto bancario. El artículo 117 de la ley de instituciones de Crédito no Viola la GARANTía DE PRIVACIDAD, Primera Sala de la Suprema Corte de Justicia de la Nación [S.G.J.N.] [Supreme Court], Semanario Judicial de la Federación y su Gaceta, Novena Época, tomo XXXIV, Julio de 2011, Tesis 1a. CXLI/2011, Página 310 (Mex.).

92 See supra note 8.

93 Chugani, supra note 53, at 606-607.

94 Id. at 608.
} 
As a result, after 9/11, twenty-seven Islamic charities were designated terrorist organizations or terrorist supporters by the US Treasury Department. Since the charity organizations were all Islamic, it was also argued that OFAC designations violated the Religious Freedom Restoration Act (RFRA) as the asset freezing measure substantially encumbers the free exercise of religious belief. ${ }^{95}$

In Holy Land Foundation for Relief \& Dev. v. Ashcroft (2002), the court considered $^{96}$ that First Amendment freedom of religion claims were debatable since the charitable organization that filed the claim had failed to prove that it was a religious organization per $\mathrm{se}^{97}$ nor did it prove that the exercise of religion had been substantially impeded. During the appeal, on the grounds that even if the charity could in fact exercise religion as protected by the First Amendment, the circuit court sustained that "there is no free exercise right to fund terrorists" and "preventing such a corporation from aiding terrorists [did] not violate any right contemplated in the Constitution or the RFRA." "98

The Mexican legal system has not experienced a bias on targeted listed persons due to their religious belief, race, political opinions or any other opinions since the sources for creating the List of Blocked Persons are other international lists and some national criminal causes. A deviation from this would not be directly attributable to the Mexican government.

\section{The Right to Free Association}

In the Holy Land Foundation for Relief \& Dev. v. Ashcroft (2002) case, it was argued that the government's actions were unconstitutional because the government's imposition of guilt due to Holy Land's association with Hamas failed to establish that the Holy Land Foundation actually had a specific intent ${ }^{99}$ to further terrorists' illegal aims, specifically those of Hamas. ${ }^{100}$ The court rejected the contention that the First Amendment required specific intent to further terrorists' unlawful aims, reasoning that the requirement of a specific intent was only involved when the government sought to impose guilt by association alone; whereas in this case, it was not mere association that created guilt, but rather the possible funding of terrorism. ${ }^{101}$ Similarly, the court also held that freedom of association had not been violated because the des-

\footnotetext{
95 Ruff, supra note 66, at 548-549.

96 Holy Land Found, 219 F. Supp. 2d 57, 83.

97 Chugani, supra note 53, at 638.

98 Holy Land Found, 333 F.3d 156, 167. Chugani, supra note 53, at 640. Ruff, supra note 66 , at 480 .

99 The intent to accomplish the precise criminal act that one is later charged with. Black's Law Dictionary, 2367 (8th ed. 2004).

100 Ruff, supra note 66, at 480.

101 Holy Land Found. 219 F. Supp. 2d at 81.
} 
ignation and blocking of funds promote governmental interests in combating terrorism by undermining its financial base, and "there is no other, narrower means of ensuring that charitable contributions to a terrorist organization are for a legitimate purpose." 102

Under the Mexican legal system, it would be difficult for the freezing of financial assets to be tantamount to a claim of free of association since the causes for including somebody on the List of Blocked People is not related to the right to participate in any association, ${ }^{103}$ but for having been included on a certain list or being involved in specific local criminal causes.

\section{The Right to Free Speech}

In the United States, designated persons argued that the First Amendment of the Constitution includes the solicitation of funds under free speech clause. According to them, this is a necessary component for the effective flow of information and citizens' ability to advocate different positions. ${ }^{104}$

Nonetheless in this respect, US courts have found an important government interest in regulating the non-speech element to justify incidental limitation to the First Amendment. According to United States v. O'Brien (1968), the elements are the following: 1) the President had the power to issue executive orders under the IEEPA; 2) an Executive order advanced an important government interest - to combat terrorism by undermining its financial bases; 3 ) this government interest was unrelated to the suppression of free expression, and 4) this incidental restriction was no greater than necessary to further government's interest. ${ }^{105}$

Under the Mexican legal system, holding that the freezing of financial assets could be viewed as an infringement of free of speech could hardly be sustained since freedom of speech can only be restricted when it "offends good morals, infringes the rights of others, incites to crime, or disturbs the public order," ${ }^{106}$ pursuant to Articles 6 and 7 of the Mexican Constitution.

\footnotetext{
102 Id. at 64. Chugani, supra note 53, at 625.

103 Cámaras de Comercio e Industria, afiliación Obligatoria. El artículo 5o. de la LEY DE LA MATERIA VIOLA LA LIBERTAD DE ASOCIACIÓN ESTABLECIDA POR EL ARTíCULO 9O. CONSTItucional, Pleno de la Suprema Corte de Justicia de la Nación [S.C.J.N.] [Supreme Court], Semanario Judicial de la Federación y su Gaceta, Novena Época, tomo II, Octubre de 1995, Tesis P./J. 28/95, Página 5 (Mex.) (explaining the scope of the right to free association).

104 Donohue, supra note 5, at 406.

105 Holy Land Found, 219 F. Supp. 2d at 81 (citing United States v. O'Brien, 391 U.S. 367, 376-77 (1968)). Ruff, supra note 66, at 481-482.

106 Constitución Política de los Estados Unidos Mexicanos [Const.], as amended, arts. 6-7, Diario Oficial de la Federación [D.O.], 5 de febrero de 1917 (Mex.).
} 
The interpretation of this right has not been extended to cover the collection of money to support ideas. ${ }^{107}$

In brief, US Courts have set forth the requirements under which freedom of speech can be restrained in terms of asset freezing. In the Mexican regime, the freezing of financial assets could hardly amount to a violation of freedom of speech.

\section{Burden of Proof}

Globally, the strategy to combat money laundering and financing terrorism has changed in recent years. Initially, it required criminalizing both money laundering and terrorism financing, pursuant to the Vienna Convention and the Palermo Convention. Then, country members were urged to adopt legislative measures that empowered their competent authorities to freeze or seize and confiscate laundered property, proceeds from, or instrumentalities used in or intended for use in money laundering or allocated for use in, the financing of terrorism, terrorist acts or terrorist organizations, without requiring a criminal conviction. ${ }^{108}$

As a way to address financing terrorist activities, criminal law has been practically replaced by administrative preventative measures, weakening the burden of proof from beyond a reasonable doubt, as required in criminal cases, to the preponderance of proof used in non-criminal cases. ${ }^{109}$ Consequently, both countries have administrative procedures for freezing assets, in addition to criminal procedures to pursue the crimes of money laundering and financing terrorism.

In the United States, the standard of proof for an SDGT designation is lower than the "beyond a reasonable doubt" for criminal procedure. Additionally, the OFAC now has the power to base SDGT designations on classified information, which is not available to the prosecution during criminal proceedings for material support of terrorism.

As a result, the difference in standards of proof applicable to a criminal trial (proof beyond a reasonable doubt) and a regulatory review (preponderance of proof) makes it highly unlikely that an acquittal in the criminal pro-

107 Libertad de expresión. Los artículos 6o. y 7O. De la Constitución Política de los Estados Unidos Mexicanos establecen derechos fundamentales del Estado de derecho, Pleno de la Suprema Corte de Justicia de la Nación [S.C.J.N.] [Supreme Court], Semanario Judicial de la Federación y su Gaceta, Novena Época, tomo XXV, Mayo de 2007, Tesis P./J. 24/2007, Página 1522 (Mex.).

108 See supra note 32. Recommendations 3 and 4.

109 Peter Gutherie, Security Council Sanctions and the Protection of Individual Rights, 60 N.Y.U. Ann. Surv. Am. L. 491, 505 (2004) (given the effects of asset freezing, it closely resembles criminal sanctions). 
cedure could challenge or affect the administrative designation. ${ }^{110}$ Furthermore, the courts have held that because terrorist financial freezing does not fall under criminal law, the defendant's claim to the Sixth Amendment right to confront accusers does not apply, ${ }^{111}$ nor does any other protection under criminal law. ${ }^{112}$

Following international standards, the Mexican administrative procedure for freezing assets is independent of criminal prosecution, and is carried out before an administrative official. As such, it is not a legal action brought before a judge.

The asset freezing measure is supplemental to a criminal process against a designated person or entity, but it is not conditional to the existence of such proceedings, according to FATF Recommendation $6 .{ }^{113}$ Consequently, the inclusion of any person or entity on the List of Blocked Persons and the resolution of the corresponding administrative procedure do not depend on the existence of criminal proceedings.

Under the relevant rules, the affected person or entity can file a claim before the FIU, where they explain the reasons their financial assets should be freed and submit the relevant evidence. Subsequently, the administrative authority has the discretionary power to decide on the case. An important difference with the US legal system is that in the Mexican regime, an acquittal of the corresponding criminal proceedings would be sufficient to remove a designee from the List of Blocked Persons.

All in all, even though both systems have administrative procedures to review the execution of asset freezing, the consequences of an acquittal in a criminal process are different. In the U.S., the administrative procedure is continued, while in Mexico the procedure is ended. Broadly, these are the main domestic legal concerns involving the freezing of assets in the context of the United States and Mexican legal systems. However, overseas, Europe-

110 Grant Nichols, Note, Repercussions and Recourse for Specially Designated Terrorist Organizations Acquitted of Materially Supporting Terrorism, 28 Rev. Litig. 263, 272-74, (2008).

111 Donohue, supra note 5, at 413.

112 Cf. Organization of American States (OAS), American Convention on Human Rights "Pact of San Jose, Costa Rica" (B-32), art. 8 para 2, 22 January 1969. (Conversely the InterAmerican Court of Human Rights has held that "regarding the determination of [the] rights and obligations of civil, labor, fiscal or any other nature by Article 8 does not specify any minimum guarantees as it does in paragraph 2 to refer criminal proceedings." However, the concept of fair trial also applies to these orders.) See also Exceptions to exhaustion of domestic remedies (art. 46.1, 46.2 and 46.2.b American Convention on Human Rights), Advisory Opinion OG-11/90, Inter-Am. CT. H.R. (ser. A) No. 11, 28 (Aug. 10, 1990); Paniagua Morales v. Guatemala, Merits, Judgment, Inter-Am. CT. H.R. (ser. C) No. 37, 149 (Mar. 8, 1998); Constitutional Court v. Peru. Merits, Reparations and Costs, Judgment, Inter-Am. CT. H.R. (ser. C) No. 31, 70 (Jan. 31, 2001); Ivcher Bronstein v. Peru. Merits, Reparations and Costs, Judgment, Inter-Am. CT. H.R. (ser. G) No. 74, 136-37 (Feb. 6, 2001).

113 See supra note 32. Interpretative note to Recommendation 6, para. 2. 
Esta revista forma parte del acervo de la Biblioteca Jurídica Virtual del Instituto de Investigaciones Jurídicas de la UNAM http://www.juridicas.unam.mx/ https://biblio.juridicas.unam.mx/bjv https://revistas.juridicas.unam.mx/ http://dx.doi.org/10.22201/iij.24485306e.2019.1.13130

an courts have reached different determinations for similar concerns. These are discussed in the following section.

\section{Beyond the US and MeXican Scope: \\ The EuRopean APPROACH}

Given that neither the United States nor Mexico offers a clear and predictable solution to freezing assets procedure for the years to come, it should be noted that Mexican and US legal interpretations may be contrasted with other interpretative legal criteria, such as those from Western Europe. In fact, several European courts have recognized the highly harmful potential of asset freezing. The main resolutions of the European courts on the issues at hand are presented below.

\section{The Use of Classified Information}

Concerning national security policy, the European Court of Human Rights has recognized that even when national security is at stake and the use of confidential information may be necessary, it does not mean that national authorities can declare that the case concerns national security and terrorism and be free from any review by national courts. ${ }^{114}$ Likewise, on the topic of secret evidence, the Court of First Instance of the European Communities (Seventh Chamber) in People's Mojahedin Organization of Iran v Council [2008] stated that the Council of the European Union is not entitled to base its decision to freeze funds on information or material in a file communicated by a Member State if said Member State is not willing to authorize its communication to the Community judicature whose task it is to review the legality of that decision. ${ }^{115}$ This refusal put the Court in a position of being unable to review the lawfulness of the contested decision. Consequently, the Court concluded that, under such circumstances, the applicant's right to effective judicial protection had been infringed. ${ }^{116}$

\section{The Right to Be Heard}

Regarding rights of defense, in particular the right to be heard, in the joined cases of Kadi and $\mathrm{Al}$ Barakaat International Foundation v Council and Commission [2008], the European Court of Justice asserted that this right had

114 Chahal v. The United Kingdom, App. No. 22414/93, Eur. Ct. H.R., 131 (Nov. 15, 1996).

115 Case T-284/08, People's Mojahedin Organization of Iran v. Council, 2008 E.C.R.

II-3487, para. 73.

116 Id. at para. 78. 
been infringed because the Council of the European Union neither communicated to the applicants the evidence used against them to justify the restrictive measures which had been imposed on them, nor afforded them the right to be informed of the evidence within a reasonable period after they were enacted. Consequently, the applicants had not been in a position to make their point of view heard in that respect. ${ }^{117}$

\section{Effective Fudicial Review}

Similarly, with reference to the right to effective judicial review, in the Kadi case, the European Court of Justice asserted that its review of the validity of any Community measure concerning fundamental rights must be considered an expression of a constitutional guarantee stemming from the European Community Treaty, which was not to be prejudiced by an international agreement - namely the Charter of the United Nations. ${ }^{118}$

Likewise, the European Court of Justice held that the Community judicature must ensure a review of the lawfulness of all Community acts in the light of fundamental rights, including a review of Community measures designed to give effect to the resolutions adopted by the Security Council under Chapter VII of the Charter of the United Nations. ${ }^{119}$ Accordingly, the European Court of Justice has stated that while the re-examination procedure carried out by the Sanctions Committee clearly failed to offer guarantees of effective judicial protection that must remain the case.

In particular, the European Court of Justice has asserted that the creation of a focal point and the Office of the Ombudsperson cannot be equated with the provision of an effective judicial procedure for the review of decisions made by the Sanctions Committee ${ }^{120}$ given that: (1) the request is a matter of inter-governmental consultation; (2) the Sanctions Committee is not obligated to consider the views of the blocked person; and (3) there was no provision other than minimal access to the information on which the decision was based to include the petitioner on the list. ${ }^{121}$

In other words, the de-listing procedure is not independent and impartial since the accuser is also the judge. It is common that the nation requesting the listing is one of the members of the body deciding whether to list or de-

117 Joined Cases C-402/05 P and C-415/05 P, Kadi and Al Barakaat International Foundation v. Council and Commission, ECJ, ECLI:EU:C:2008:461, para. 348. Aff'd T-85/09

(2010), Kadi v. European Commission, ECLI:EU:T:2010:418, paras. 180-88

118 Joined Cases C-402/05 P and C-415/05 P, para. 316.

119 Id. para. 326.

120 Id. paras 322-325.

121 Opinion of Advocate General Poiares Maduro, delivered on 16 January 2008, Case C-402/05 P, Yassin Abdullah Kadi v. Council of the European Union and Commission of the European Communities, para. 46. 
Esta revista forma parte del acervo de la Biblioteca Jurídica Virtual del Instituto de Investigaciones Jurídicas de la UNAM http://www.juridicas.unam.mx/ https://biblio.juridicas.unam.mx/bjv https://revistas.juridicas.unam.mx/

http://dx.doi.org/10.22201/iij.24485306e.2019.1.13130

list a person. ${ }^{122}$ Therefore, the Court of Justice concluded that the applicants suffered an infringement of their right to effective judicial review because of the failure to inform the applicant of the evidence given against him and the inability to defend his rights regarding the evidence in question in satisfactory conditions before the Community judicature. ${ }^{123}$ In short, while no other instance affords real access to judicial protection, ${ }^{124}$ domestic European courts are rather concerned about providing minimal procedural safeguards in European Union courts.

\section{Infringement of Property Rights}

In this regard, in the Kadi case, the European Court of Justice concluded that the applicants suffered from an infringement of their right to property, resulting from the freezing measures imposed under Regulation No 881/2002. This measure was adopted without providing any guarantee that would enable a designated person or entity to bring his case before the competent authorities. Such a general application and actual open-ended continuation of the restrictive measures constituted an unjustified far-reaching restriction of his peaceful enjoyment of property with potentially devastating consequences, even when arrangements are made for basic needs and expenses. ${ }^{125}$

\section{The Right to Freedom of Movement}

In Ahmed and Others, the Supreme Court of the United Kingdom was of the opinion that designated persons were effectively 'prisoners' of the State as their freedom of movement was severely restricted without access to their funds and the effect of asset freezing on them and their families can be devastating. $^{126}$

122 Abdelrazik v. Canada (Minister of Foreign Affairs), [2010] 1 FCR 267, 2009 FC 580 (CanLII), para 51; cited in Her Majesty's Treasury v. Mohammed, para. 69.

123 Joined Cases G-402/05 P and C-415/05 P, para 349, aff'd, T-85/09 (2010), paras. 180-88.

124 Gutherie, supra note 109, at 514 (the current review of listing decisions seems more political than legal).

125 Joined Cases C-402/05 P and C-415/05 P, para. 366, aff'd, T-85/09 (2010), paras. 192-95.

126 Her Majesty's Treasury v. Mohammed Jabar Ahmed and others; Her Majesty's Treasury v. Mohammed al-Ghabra; R (on the application of Hani El Sayed Sabaei Youssef) v. Her Majesty's Treasury, [2010] UKSC 2, United Kingdom: Supreme Court, para. 104, 27 January 2010. 


\section{Final Remarks. Preventing Money Laundering and Financing Terrorism in Mexico: Lessons from US and European Domestic Frameworks}

The Mexican regime on financial asset freezing in the context of preventing money laundering and countering terrorist funding suffers from a lack or a reduction of civil liberties, which leaves the affected persons with a weak possibility to conduct a proper defense. In Mexico, financial statutory laws and regulations do not afford sufficient due process protection when the corresponding administrative procedure fails to order a notice to be served even after the assets have been frozen. Furthermore, the administrative procedure is not focused on challenging the designation itself, but on correcting false positives. However, it is possible to grant more effective human rights protection without endangering measures to suppress terrorism and money laundering.

To better protect human rights in the Mexican legal system, some suggestions are:

1. The designated person or entity should be notified without delay after asset freezing has been executed so as to grant those affected a real opportunity to defend existing rights.

2. Mexican Secretariat of Finance should endeavor to serve notice of the reasons for listing the person, entity or group concerned. When this notification is not possible or in any other case, a notice should be published in the Federal Official Gazette to inform those concerned of the applicable procedures. These measures would not hinder the deployment of UN resolutions or FATF recommendations or reduce their efficacy, considering their resolutions and list are publicly available. Yet, people would concurrently enjoy due process protection.

3. Since long-term freezing of assets might amount to a governmental act of deprivation under the Mexican legal system, specific time limits on the blocking of assets would lessen the hardship on civil rights. It also would provide the government with an incentive to present criminal charges quickly, start a civil procedure on the property deprivation, or to release the funds. Alternatively, to the extent that asset freezing could last indefinitely, a hearing before judicial courts should be granted.

4. Some rules or principles to guide the assessment of the requests to access frozen funds to pay the blocked person's defense expenses should be provided. It would avoid conflict of interest claims and mitigate the risk of the resulting decision being challenged as arbitrary, without any basis or against the law.

5. The List of Blocked Persons should be made public or, at least the section concerning UN sanctions. This would not only allow better compliance of the Mexican government's international commitments, but also grant better protection of human rights to designees. Currently, 
Esta revista forma parte del acervo de la Biblioteca Jurídica Virtual del Instituto de Investigaciones Jurídicas de la UNAM http://www.juridicas.unam.mx/ https://biblio.juridicas.unam.mx/bjv https://revistas.juridicas.unam.mx/ http://dx.doi.org/10.22201/iij.24485306e.2019.1.13130

the reasons to be added to the List of Blocked Persons include not only those blacklisted by the Un sanction committees and other international organizations' lists, but also local criminal causes. Consequently, in order to not contaminate UN sanction regimes and its requirements, the relevant procedures should be unambiguously separated from the cases containing local criminal causes. 